\author{
Adam Jakub Jarych \\ https://doi.org/10.26485/AAL/2020/66/5
}

\author{
FUNDACJE ŚWIĄTYŃ EX MANUBIIS \\ W OBRĘBIE CYRKU FLAMINIUSZA ${ }^{1}$
}

\begin{abstract}
ABSTRAKT Wykorzystanie łupów na działalność budowlaną miało w Rzymie długą tradycję, sięgającą czasów etruskich królów, którzy w ten sposób sfinansowali część prac nad świątynią Jowisza Kapitolińskiego. Niniejszy artykuł skupia się na historii dziewięciu przybytków, które miedzy III a I w. p.n.e. zostały ufundowane przez zwycięskich wodzów ex manubiis w obrębie Cyrku Flaminiusza. Miejsce to wybierane było nieprzypadkowo, gdyż wielu antycznych pisarzy uważało je za jedną z najpiękniejszych części Rzymie, gdzie m.in. przebiegała trasa triumfalna. Cyrk był ponadto otwartym placem otoczonym z każdej niemal strony świątyniami i portykami, w których wnętrzach eksponowano zdobycz wojenną, podkreślającą splendor rzymskiego oręża.
\end{abstract}

Słowa kluczowe: Łupy wojenne, świątynie, ex manubiis, Circus Flaminus

\title{
FOUNDATION OF EX MANUBIIS TEMPLE \\ IN THE CIRCUS FLAMINIUS
}

\begin{abstract}
The use of booty on construction activity in ancient Rome, was practiced in the times of the Kings, when Tarquinius financed the construction of the Temple of Jupiter in such a way. In this article, I would like to gather together the ex manubiis foundations, which were erected during the whole period of the Republic within the Circus Flaminius. According to the surviving literary and archaeological sources, we can detect this method being used to finance the building of temples in the case of nine buildings. The Circus Flaminius was a very important area for victorious generals on account of their being able to present the effects of their military campaigns. Moreover, at this point run triumphal road, which was flanked on each side with ex manubiis temples which emerged almost every year.
\end{abstract}

Key words: Booty, temples, ex manubiis, Circus Flaminius

Przy tym Polu [Campus Martius - A. J.] jest kolejne Pole [Circus Flaminius - A. J.] z wieloma kolumnami, świętymi pomieszczeniami, trzema teatrami, amfiteatrem oraz bardzo kosztownymi świątyniami, co daje wrażenie, że reszta miasta jest tylko dodatkiem. Dlatego téz $w$ tym miejscu [Rzymianie - A. J.], budowali grobowce najwybitniejszych mężczyzn i kobiet, gdyż [Pole Marsowe A. J.], uchodziło za najświętsze ze wszystkich [...] (przeł. J. Dworniak, A. Jarych) ${ }^{2}$.

1 Artykuł ten jest częścią nieopublikowanej rozprawy doktorskiej autora pt. Ornamenta urbis et publica magnificentia. Wykorzystanie zdobytych dziet sztuki $w$ przestrzeni republikańskiego Rzymu w okresie od IV do I wieku p.n.e., która została napisana pod kierownictwem prof. Ilony Skupińskiej Løvset.

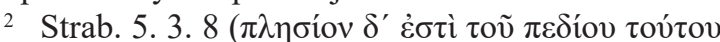

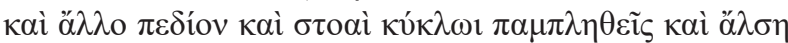

W ten sposób region Circus Flaminius charakteryzuje piszący w I w. n.e. Strabon. Geograf z Pontu, przebywający na Półwyspie Apenińskim w okresie pryncypatu Augusta, zachwycił się tym miejscem, w którym od schyłku III w. p.n.e. kwitło życie publiczne Rzymu, zorganizowane wokół dwóch sfer: militarnej oraz społeczno politycznej ${ }^{3}$. Teren ten był bowiem wykorzystywany w rozmaity sposób, m.in. w celach handlowych, ale także podczas organizacji igrzysk (ludi),

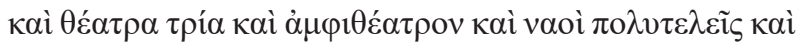

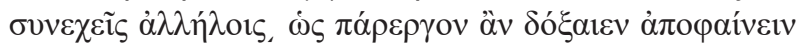

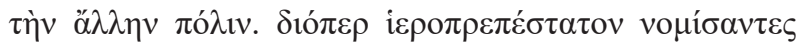

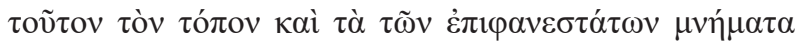
$\dot{\varepsilon} v \tau \alpha \tilde{v} \theta \alpha \kappa \alpha \tau \varepsilon \sigma \kappa \varepsilon v ́ \alpha \sigma \alpha v \dot{\alpha} v \delta \rho \tilde{v} v \kappa \alpha i ̀ ~ \gamma v v \alpha ı \kappa \tilde{v} v[.]$.$) .$

$3 \mathrm{Na}$ temat Circus Flaminius, zob. Castagnoli 1948: 91-193; Wiseman 1974: 3-26; Viscogliosi 1993a: 269-272; Coarelli 1997: 363. 
zgromadzeń ludowych (m.in. concilium plebis), czy jako obszar, gdzie zbierało się wojsko ${ }^{4}$.

W niniejszym artykule skupiam się na aspekcie, który bezpośrednio związany jest z pierwszą $\mathrm{z}$ wymienionych sfer, a mianowicie na wykorzystaniu łupów wojennych na fundację świątyń ${ }^{5}$, które na przestrzeni lat wznoszono $\mathrm{w}$ obrębie Cyrku Flaminiusza, bowiem niemal każdy z wymienionych przez Strabona monumentów został ufundowany ex manubiis ${ }^{6}$. Termin ten ma szerokie znaczenie i nie będę go dokładnie analizować w tym miejscu. Należy zaznaczyć jednak, że może on określać zagarnięte podczas działań militarnych: a) pieniądze bądź kruszec, b) pieniądze zarobione ze sprzedaży łupów, c) pozostałą zdobycz tj. dzieła sztuki, broń czy inne wartościowe przedmioty?

Wszystkie wyżej wymienione manubiae były wykorzystywane przy wznoszeniu monumentów. I tak, o ile najważniejszym z nich były pieniądze, dzięki którym pokrywano wszelkie koszty związane $\mathrm{z}$ budową, to splądrowane dzieła sztuki stanowiły ich dekorację i nośnik wartości reprezentowanych przez poszczególnych wodzów, którzy za sprawą fundacji publicznych mogli na stałe zapisać się w świadomości obywateli - wyborców, podkreślając przy tym własną chwałę (gloria et laus) ${ }^{8}$.

Teren Circus Flaminius nadawał się do takich prezentacji idealnie, bowiem dzięki swojemu położeniu miał od samego początku silne konotacje z każdym triumfem. Tu bowiem zbierało się wojsko przed pompa triumphalis. $\mathrm{W}$ jego obszarze wystawiano także łupy wojenne oraz wypłacano za ich pośrednictwem pieniądze (manubiae, praeda) dla legionistów. W tym miejscu wodzowie odznaczali również swoich żołnierzy nagrodami za zasługi podczas kampanii (dona militaria) ${ }^{9}$. Nie może zatem dziwić fakt, że przestrzeń ta była chętnie zagospodarowywana przez poszczególnych dowódców, którzy in circo wznieśli tak wiele fundacji.

4 Wiseman 1974: 4.

5 Don Miller 2013: 191-192. Oprócz świątyń ex manubiis fundowane były również inne monumenty publiczne tj. portyki, forniksy, kolumny czy fora.

6 Shatzman 1972: 177-205. W łacinie znajdziemy wiele zwrotów związanych z łupami, oprócz manubiae również praeda i spolia. Jednak jeśli źródła wspominają o budowie poszczególnych fundacjach publicznych, wykorzystaną na ten cel zdobycz, określano głównie pierwszym z wymienionych terminów.

7 Shatzman 1972: 177-205.

8 Don Miller 2013: 191-192.

9 Liv. 39. 5. 5-6; Plut. Luc. 37. Na ten temat zob. Maxfield 1981.
Zaznaczyć należy jednak, że pisząc o monumentach zbudowanych za pośrednictwem zdobyczy wojennej, skazani jesteśmy w wielu miejscach na spekulacje, co spowodowane jest ograniczonym korpusem źródeł, szczególnie do pierwszych dziesięcioleci III w. p.n.e. Dlatego w niniejszym artykule będę opierał się na ustaleniach Adama Ziółkowskiego, który w swojej rozprawie doktorskiej podzielił budowle ex manubiis na trzy kategorie $^{10}$. Do pierwszej z nich zaliczył fundacje, co do których przekazy narracyjne i epigraficzne są jednoznaczne i w sposób bezpośredni wzmiankują o wykorzystaniu zdobyczy. W skład drugiej grupy włączone zostały obiekty, które były ślubowane podczas kampanii wojennej, a których budowa $\mathrm{z}$ manubiae jest prawdopodobna. $\mathrm{W}$ trzecim punkcie historyk umieścił budowle, których fundacja ex manubiis jest najmniej prawdopodobna. Choć zostały one wzniesione przez byłych magistratów, prowadzących działania wojenne, podczas których mogli zgromadzić manubiae, to w źródłach brakuje jednoznacznych wzmianek na ten temat ${ }^{11}$. Ponadto na uwagę zasługuję fakt, iż pomimo tego, że przybytki dedykowane bogom powstawały w Rzymie już od najwcześniejszych lat, to jednak aż do III w. p.n.e. obszar Pola Marsowego nie stanowił atrakcyjnego terenu pod budowę tego typu fundacji. Niestety, nie jest jasne dlaczego przestrzeń ta była pomijana we wczesnym okresie Republiki. Być może było to związane z pewnymi ograniczeniami religijnymi, gdyż teren ten, według jednej $z$ tradycji, był poświęcony Marsowi, bądź też z powodu przynależności tego gruntu do wygnanego z miasta Tarkwiniusza Pysznego ${ }^{12}$

Niewykluczone jednak, że powód pomijania tego obszaru był bardziej prozaiczny i związany z warunkami naturalnymi. To właśnie ta część Rzymu była narażona na częste wylewy Tybru ${ }^{13}$. Wystarczy wspomnieć, że podczas inauguracji Teatru Balbusa (który znajdował się na północ od

10 Ziółkowski 1980 (maszynopis w zbiorach Uniwersytetu Warszawskiego).

11 Ziółkowski 190: 371, zob. również Pietilä-Castrén 1987; Weigel 1998: 119-142; Bastien 2008: 2948, contra Orlin 2002. Orlin uważa natomiast, że tylko w przypadku pięciu świątyń możemy mówić bezpośrednio, że zostały sfinansowane z łupów wojennych.

12 Muccigrosso 2006: 188-191. W okresie od VI do IV w. p.n.e. świątynie najczęściej były fundowane w obszarze Forum Romanum, Circus Maximus czy przy najważniejszych miejskich drogach. W tych latach tylko przybytek dedykowany Apollinowi znalazł się na Polu Marsowym.

13 Ball Platner, Ashby 1929: 91-94. 
Circus Flaminius) widzowie mogli dostać się do tego monumentu tylko łodziami, ponieważ wylew rzeki uniemożliwiał pieszy dostęp ${ }^{14}$. Podtopienia Pola Marsowego nie były problemem tylko w czasach antycznych. Zdarzały się one także w okresie nowożytnym, co widać chociażby na licznych fotografiach, na których uwieczniono m.in. powódź Rzymu z roku 1900.

\section{Lokalizacja i struktura Circus Flaminius}

Analizę poszczególnych świątyń zbudowanych w tej części miasta należy rozpocząć od przybliżenia lokalizacji oraz struktury Circus Flaminius. Nazwa tego obiektu z jeden strony odnosiła się bezpośrednio do ufundowanego przez Gajusza Flaminiusza Neposa w latach 223-220 p.n.e. cyrku ${ }^{15}$, z drugiej zaś charakteryzowała region, $\mathrm{w}$ obrębie którego fundowano budowle publiczne ${ }^{16}$.

Antyczne przekazy na temat początków circus nie są jednoznaczne. Według źródeł teren Campus Martius stanowił pierwotnie ager Tarquinorum, który w okresie Republiki został przekształcony $\mathrm{w}$ ager publicus ${ }^{17}$. Niestety, przy obecnym stanie źródeł nie można stwierdzić czy południowa część Pola Marsowego, gdzie od lat dwudziestych III w. p.n.e. znajdował się Circus Flaminius wchodziła w skład ziemi należącej do rzymskich królów. Jak zaznaczył bowiem Liwiusz, cyrk zajmował przestrzeń dawnej prata Flaminia, nazywanej przez Warrona także campus Flaminius ${ }^{18}$. Podobnie jak w przypadku Pola Marsowego, określenie właściciela tych gruntów jest dyskusyjne. Orozjusz uważał, że teren ten należał aż do I w. p.n.e., do kolegium flaminów. Niewykluczone jednak, iż mógł on zostać przyznany jednemu z przedstawicieli gens Flaminia jako działka, którą - jak zaznaczył Plutarch - Flaminiusz przeznaczył na cyrk ${ }^{19}$.

14 Cass. Dio, 54. 25. 2. O podtopieniach tej części miasta wspominał m.in. Liwiusz, zob. Liv. 35. 21. 5-6.

15 Liv. Per. 20; Fest. 79L. Na temat kariery politycznej Flaminiusza, zob. Broughton 1951: 235-236. W przypadku daty fundacji dysponujemy dwoma różnymi przekazami. Według Liwiusza Circus Flaminius powstał w roku 220 p.n.e. podczas sprawowania przez Flaminiusza urzędu cenzora. Festus uważa natomiast, że trzy lata wcześniej, kiedy wódz ten prowadził działania militarne przeciwko Insubrom.

16 Petruccioli 2002: 86-87.

17 Liv. 2. 5. 2; Dion. Hal. Ant. Rom. 5. 13.

18 Liv. 3. 54. 15; Varro. Ling. 5. 154; Petruccioli 2002: 86-87.

19 Plut. QR. 66; Oros. 5. 18. 27.
Sama lokalizacja jak i struktura tego monumentu przez długie lata była tematem ożywionych dyskusji. Według koncepcji Ferdinando Castagnolego Pole Marsowe należy interpretować na dwa sposoby: a) ogólnie, jako równinę znajdującą się na północny - zachód od Kapitolu, do której zaliczał się również Circus Flaminius, bądź b) szczegółowo, jako małą przestrzeń leżącą na zachód od źródła Petronia Amnis. W przypadku drugiej koncepcji cyrk nie był integralną częścią Campus Martius, i jak sądzono już w okresie renesansu, znajdował się on na północ od Porticus Octaviae i Porticus Philippi, gdzie był łączony z pozostałościami arkad i murów zachowanych przy współczesnej Via delle Botteghe Oscure ${ }^{20}$. Podział ten miał wyjaśnić, dlaczego niektóre świątynie (m. in. świątynia Marsa) lokalizowane były z jednej strony in circo, kolejnym razem zaś in campo, co sprawiło, że cyrk traktowany był jako suwerenna przestrzeń względem reszty Pola Marsowego ${ }^{21}$. Dublowało to ponadto wszystkie przybytki z obu obszarów.

Analiza Castagnolego oparta była jednak na błędnym usytuowaniu cyrku oraz jego struktury architektonicznej. Guglielmo Gatti rekonstruując fragmenty Forma Urbis Romae (= FUR) (30ii oraz $31 \mathrm{cc}$ ), na których zachowała się część napisu - Cir[cus] Flami[nius] - oraz wspominane wyżej portyki, wykazał że circus znajdował się nie na północ, ale na południe od obu monumentów. $\mathrm{Na}$ tej podstawie przeniósł on fundację Flaminiusza w południowo - wschodnią część Pola Marsowego, co implikowało również przesunięcie wszystkich świątyń ${ }^{22}$. Dzięki tej rekonstrukcji oraz za sprawą badań archeologicznych wiemy, iż zwrotu in circo nie należy tłumaczyć dosłownie jako „wewnątrz cyrku”, tylko „przy jego krawędzi”.

Monument ten był bowiem otwartym placem, który nie miał stałej bryły jak m.in. Circus Maximus. Poszczególne zaś boki tego założenia były ograniczone przez budowle, które w tym miejscu wznosili głównie triumfujący wodzowie (m.in. świątynie i portyki) ${ }^{23}$. Plac ten rozciągał się na osi północny-zachód, południowy-wschód, z przesuniętą o $30^{\circ}$ orientacją względem Pola Marsowego ${ }^{24}$.

20 Castagnoli 1948: 112-127. Obecnie pozostałości te łączone sa już z Teatrem Balbusa, zob. Gatti 1960: 3-12.

21 Liv. 39. 2: 11; Inscr. Ital. 13. 2: 25.

22 Gatti 1960: 3-12.

23 Liv. 3. 54. 15; Varro, Ling. 5. 146; Plut. Quaest. Rom. 66; Viscogliosi 1993a: 269-272. W czasie igrzysk przestrzen cyrku mogła być ograniczona drewnianymi trybunami.

24 Rodriguez-Almeida 1991-1992: 5. 
Dlatego nie może dziwić fakt, że pewne świątynie (m.in. aedes Pietas), lokalizowane in foro Holitorio, są również określane jako budowle znajdujące się in circo $^{25}$.

Zanim jednak cyrk został wytyczony w południowo-wschodnim obszarze Campus Martius, w miejscu tym znajdowały się już trzy świątynie: Apollina, Bellony i Neptuna, z których dwie ostatnie ufundowano prawdopodobnie ex manubii ${ }^{26}$.

2. Świątynie z obszaru Cyrku Flaminiusza (in campo / in circo Flaminio / ad circum Flaminium)

\section{1. Świątynia Bellony (Bellona, aedes $)^{27}$}

Świątynia Bellony była, obok przybytku Apollinis Medici ${ }^{28}$, najstarszą aedes znajdującą się w tej części Rzymu i prawdopodobnie pierwszą, którą sfinansowano w tym rejonie Miasta

25 Liv. 40. 34. 4-6; Obs. 54

26 Bastien 2008: 32-35. Zachowane przekazy wymieniają jeszcze jedną świątynię znajdującą się in circo Flaminio i wzniesioną przed fundacją tego monumentu. Według Fasti Vallenses w tym obszarze stał przybytek Wulkana. Jednak jego dokładna lokalizacja jak i sama fundacja jest niejednoznaczna. Liwiusz zaznaczył bowiem, że świątynię tę zbudowano in campo, co sugeruje, że przybytek powinien znajdować się przy północnej stronie circus. Jak wykazał jednak Manacorda, aedes ta nie stała bezpośrednio przy północnej krawędzi cyrku, tylko za tymi świątyniami w obszarze na zachód od Teatru Balbusa i na południe od Area Sacra. Badacz ten uważa, że przybytek Wulkana znajdował się na południe od świątyń z obecnego Largo di Torre Argentina i stał on w szeregu trzech monumentów, które przedstawione sa na fragmencie Forma Urbis Romae (234a,b,c). Wspominam o tym przybytku nieprzypadkowo, gdyż Ziółkowski zasugerował, że również ta świątynia mogła powstać jako wotum jednego z rzymskich wodzów. Historyk nie wyklucza, iż monument ten ślubował podczas swojej kampanii Gajusz Aureliusz Kotta, który w roku 252 p.n.e. podbił Wyspy Liparyjskie, gdzie czczony był Wulkan. Ziółkowski połączył tym samym serię denarów wybitych w roku 103 p.n.e. przez Lucjusza Aureliusza Kottę, na których przedstawiono Wulkana w wieńcu laurowym, co miało nawiązywać bezpośrednio do triumfu jego przodka Gajusza Aureliusza Kotty, zob. Mancorda 1990: 35-51; Ziółkowski 1992: 181-182.

27 Viscogliosi 1993b: 190-2.

28 Liv. 4. 25. 3; Liv. 4. 29. 7; Asc. 80-81. Wzniesiony bowiem w latach 443-441 p.n.e. przybytek Apollina ufundowano z inicjatywy Senatu, po zasięgnięciu opinii z ksiąg sybillińskich. W I w. p.n.e. został on odbudowany przez Gajusza Sozjanusa. z łupów wojennych ${ }^{29}$. Ślubował ją w czasie bitwy z Etruskami i Samnitami w roku 296 p.n.e. Appiusz Klaudiusz Caecus ${ }^{30}$. Choć źródła nie wspominają bezpośrednio o tym, że jej budowa została sfinansowana z manubiae, to zważywszy na ilość zdobytych podczas kampanii łupów ( $p r a-$ eda ingens parta) jest to najbardziej prawdopodobna możliwość ${ }^{31}$.

Niestety, ograniczony korpus źródeł uniemożliwia nam określenie roku dedykacji świątyni. Wiemy natomiast, że jej dies natalis przypadał trzeciego czerwca ${ }^{32}$.

Do naszych czasów zachowało się sporo przekazów literackich oraz źródeł archeologicznych, które umożliwiają określenie lokalizacji oraz ogólnego jej wyglądu. Według Fasti Venusini świątynia znajdowała się in circo Flaminio, co potwierdza Owidiusz, który zaznaczył, że: prospicit a templo summum brevis area circum $^{33}$. O takiej lokalizacji pośrednio świadczą także dwa passusy Plutarcha.

W pierwszym przypadku grecki autor wspomina, że gdy Sulla zwołał Senat w przybytku Bellony, zgromadzeni $\mathrm{w}$ tym miejscu senatorowie słyszeli jęki mordowanych nieopodal w cyrku $\left(i \pi \pi\right.$ ó $\rho \mu_{0} \varsigma^{34}$ i przy Villa Publica sześciu tysięcy jeńców, których pojmano w czasie bitwy przy Porta Collina ${ }^{35}$. Biograf z Cheronei informuje ponadto, że przed świątynią Bellony Cyceron wygłosił mowę w obronie pretora Marka Otona, wygwizdanego w teatrze podczas ludi Apollinares ${ }^{36}$.

Fakt, że na czas tych igrzysk wznoszono aż do schyłku I w. p.n.e. prowizoryczne sceny, które ustawiano najczęściej nieopodal świątyni Apollinis Medici (w miejscu późniejszego Teatru Marcellusa), skłonił Filippo Coarellego do postawienia tezy, że przybytek Bellony musiał znajdować się w pobliżu tych dwóch budowli. Na tej podstawie archeolog połączył tę fundację z odkrytym w latach 1932-1939 fragmentem betonowego

29 Bastien 2008: 32-33. Autor ten w swoim artykule przedstawia katalog wszystkich świątyń wzniesionych ex manubiis Rzymie w okresie IV-I w. p.n.e.

30 Liv. 10. 19. 17; CIL 6. 40943 = ILS 54; Ziółkowski 1992: 247. Na temat działań wodza podczas kampanii, zob. Broughton 1951: 176.

31 Liv. 10. 19. 17. Liwiusz wzmiankuje tylko, że zdobycz została rozdana legionistom, nie wspomina on jednak czy cała, czy tylko jej część.

32 Inscr. Ital. 13. 2: 58.

33 Ov. Fast. 6. 201-203; Inscr. Ital. 13. 2 : 58.

34 Plut. Sull. 30. 2.

35 Liv. Per. 88 ; Flor. Epit. 2. 9. 24.

36 Plut. Cic. 13. 2-4. 


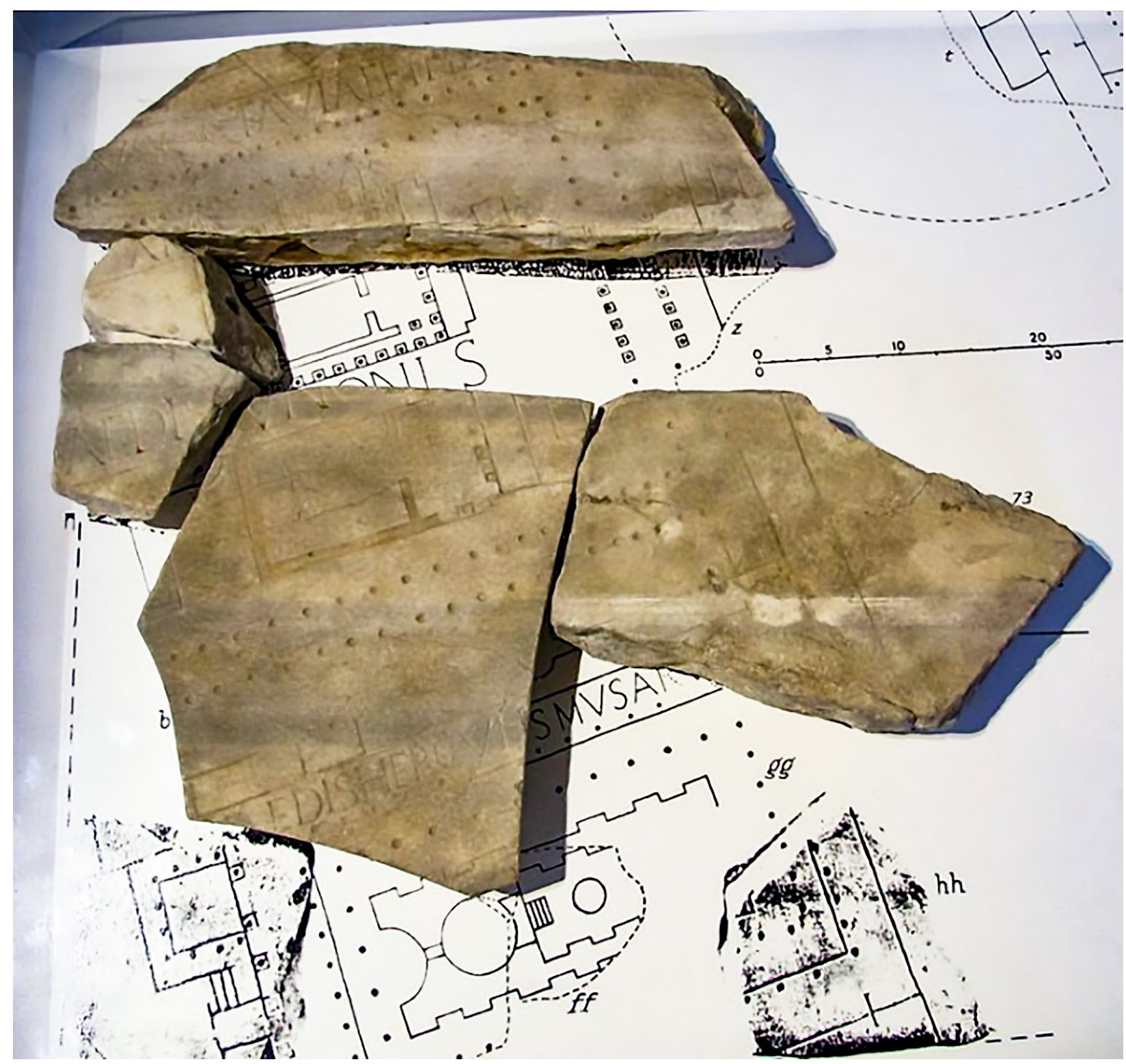

Ryc. 1. Fragmenty Forma Urbis Romae ze świątyniami znajdującymi się przy północnej krawędzi Cyrku Flaminiusza (wikimedia)

podium, które, aż do czasu publikacji jego badań określane było jako „tempio sconosciuto" ${ }^{37}$.

Pozostałości te znajdują się na wschód od przybytku Apollina i są orientowane na osi północ - południe w kierunku Forum Holitorium, gdzie, jak zasugerował Coarelli, prawdopodobnie zgromadzili się widzowie podczas przemówienia Cycerona. Świątynię zbudowano więc przy wschodniej krawędzi późniejszego Circus Flaminius i ograniczono ją od północy i zachodu kolumnadą, która biegła $\mathrm{w}$ stronę forum ${ }^{38}$. Dla części badaczy wybór tego miejsca nie był przypadkowy, bowiem uważa się, iż przybytek

37 Coarelli 1968: 37-72; Ziółkowski 1992: 18.

38 Coarelli 2008; 313. znajdował się nieopodal grobowca należącego do gens Claudia, który być może wzniesiono na zachodnim zboczu Kapitolu ${ }^{39}$. Z drugiej strony przestrzeń ta była niezwykle istotna dla wodzów, ponieważ prawdopodobnie $\mathrm{w}$ tym miejscu przebiegała droga triumfalna, która wychodząc z cyrku skręcała w kierunku porta triumphalis i biegła dalej na Forum Boarium ${ }^{40}$.

Oprócz pozostałości archeologicznych, pewnych informacji na temat wyglądu świątyni Bellony dostarcza fragment FUR (31d), na którym przedstawiono część podium oraz

39 Viscogliosi 1993b: 191. Kwestia lokalizacji grobowca jest jednak dyskusyjna.

40 F. Coarelli 2000: 148. 
kolumnady biegnącej wzdłuż poszczególnych boków przybytku. Aedes została wzniesiona na wysokiej podstawie jako perypteros z sześcioma kolumnami na krótszych bokach i dziewięcioma na dłuższych. Jej cela mierzyła $14 \times 21 \mathrm{~m}^{41}$. Niestety, większa część bloków tufu wulkanicznego, z którego wzniesiono świątynię została rozkradziona i wykorzystana wtórnie. W I w. p.n.e. przybytek odbudował Appiusz Klaudiusz Pulcher, prawdopodobnie po swoim triumfie ex Hispania (33/32 r. p.n.e. $)^{42}$. W tym też okresie część dekoracji jak i kolumn flankujących celle wykonano $\mathrm{z}$ marmuru pozyskiwanego $\mathrm{w}$ Luni. $\mathrm{Z}$ odkrytych pozostałości na szczególną uwagę zasługują kapitele $(0.80 \times 0.65 \mathrm{~m})$, które swą stylistyką miały oddawać wojowniczy charakter Bellony, gdyż $\mathrm{w}$ centralnej ich części umieszczono tropajon w stylu lorica musculata, flankowany motywami roślinnymi (liście akantu, palmy oraz owoce ${ }^{43}$. Przedstawiciele gens Claudia odpowiedzialni byli także za część dekoracji znajdującej się wewnątrz świątyni, gdzie umieszczone zostały imagines clipeatae $^{44}$.

Lokalizacja przybytku extra pomerium sprawiła, że aedes była częstym miejscem posiedzeń senatorów, którzy w jej wnętrzu wysłuchiwali raportów ubiegających się o przyznanie triumfu wodzów $^{45}$. W świątyni podejmowano także przedstawicieli wrogich Rzymowi państw ${ }^{46}$. Nie może więc dziwić fakt, że przed aedes znajdował się plac z kolumną tzw. Columna Bellica, przy której od czasów wojny z Pyrrusem rytualnie rozpoczynano kampanie militarne ${ }^{47}$.

41 De Nuccio 2011: 204.

42 La Rocca 1987: 366.

43 De Nuccio 2011: 220.

44 Plin. NH. 35. 12; Flower 1996: 75. Wizerunki przodków w świątyni zostały umieszczone prawdopodobnie przez konsula roku 79 p.n.e. Appiusza Klaudiusza Pulchera.

45 Liv. 26. 21. 1. W świątyni Bellony raport $\mathrm{z}$ kampanii na Sycylii składał Marek Klaudiusza Marcellus. Drugim przybytkiem, w którego murach podejmowano powracających z kampanii wodzów była aedes Apollinis.

46 Liv. 30. 40. 1. Po bitwie pod Zamą Senat przyjął posłów z Kartaginy, a także przedstawicieli Filipa V w świątyni Bellony.

47 Ov. Fast. 6. 205; Serv. Aen. 9. 52; La Rocca 1993: 300-301. La Rocca uważa, że okrągły blok trawertynu odnaleziony między świątynią, a Teatrem Marcellusa jest pozostałością po kolumnie. Na temat rytuału wypowiadania wojny przez facjała, zob. Popławski 2011: 51-52.

\section{2. Świątynia Neptuna (Neptunus, aedes) ${ }^{48}$}

W przypadku świątyni Neptuna dysponujemy źródłami, które wzmiankują o kulcie boga w obrębie cyrku już w III w. p.n.e. Według Liwiusza w miejscu tym znajdowała się ara Neptuni mullo manasse sudore in Circo Flaminio dicebatur ${ }^{49}$. Kasjusz Dion wyliczając prodigia roku 206 p.n.e. również wspomina o ołtarzu oraz o drzwiach świątyni ${ }^{50}$. O przybytku dedykowanym Neptunowi w tej części miasta wiemy także za sprawą przekazów epigraficznych, według których aedis Neptuni quae est in circo Flaminio ${ }^{51}$.

Niestety źródła te nie wspominają, kto był odpowiedzialny za budowę aedes. Jedynym przekazem, który łączy konkretną osobę ze świątynią jest ustęp z Historii Naturalnej Pliniusza Starszego. Autor zaznaczył, iż w przybytku Gnejusza Domicjusza Ahenobarbusa (delubro Cn. Domitii in circo Flaminio) znajdowały się posagi autorstwa Skopasa, przedstawiające orszak Neptuna ${ }^{52}$. Passus ten niestety niczego nie rozwiązuje w sprawie fundatora, bowiem pierwszym wodzem $\mathrm{z}$ tego rodu był dopiero konsul roku 192 p.n.e. ${ }^{53}$ Jak zaznaczyłem wyżej, świątynię ufundowano w III a nie II w. p.n.e. Sam zaś Ahenobarbus nie prowadził kampanii na morzu, tylko na lądzie gdzie walczył na terytorium Bojów. W takim wypadku nie może on być brany pod uwagę, jako ewentualny fundator przybytku Neptuna.

Obecnie część badaczy skłania się zatem do koncepcji, mówiącej o tym, że świątynię wzniesiono in circo prawdopodobnie w czasie I wojny punickiej bądź I wojny iliryjskiej. Zważywszy na charakter większości budowli ufundowanych w tej części Rzymu (monumentów ślubowanych podczas kampanii wojennych) przypuszcza się, że za jej budowę odpowiadał $d u x$, który celebrował, podobnie jak Gajusz Duiliusz, triumphus navalis. Fakt, że pierwszy triumf morski odbył się w roku 260 p.n.e. skłonił uczonych do datowania aedes na lata $257-228$ p.n.e. ${ }^{54}$ Pier Luigi Tucci uważa na tej podstawie, że za budowę przybytku mógł odpowiadać Marek Emiliusz Paulus, który z powodzeniem walczył przeciwko punickiej flocie w roku

48 Tucci 2000: 279. Rytuał ten przywrócił po latach August.

49 Liv. 28. 11. 4.

50 Cass. Dio, 17. 57. 60

51 CIL 6. 8423.

52 Plin. NH. 36. 26.

53 Liv. 35. 22. 4; Broughton 1951: 350; Ziółkowski

1992: 117-118.

54 Ziółkowski 1992: 118; Coarelli 1997: 404. 
255 p.n.e. ${ }^{55}$ Żadne źródła nie potwierdzają jednak czy był on odpowiedzialny za tę fundację. Niestety, podobnie jak w przypadku świątyni Bellony nie posiadamy informacji, co do roku jej dedykacji. Wiemy jedynie, że jej dies natalis wypadało pierwszego grudnia ${ }^{56}$.

Niemniej jednak świątynia musiała powstać przed rozpoczęciem prac nad Circus Flaminius, gdyż jej orientacja znacznie odbiega od późniejszych budowli ufundowanych w tym miejscu, które korelują w sposób bezpośredni ze strukturą cyrku. Warto przy tym zaznaczyć, że jest ona ustawiona tak samo jak wspominany wyżej przybytek Bellony, a więc na osi północ - południe ${ }^{57}$.

$\mathrm{W}$ związku z powyższym wzmiankowany przez Pliniusza Starszego, Gnejusz Domicjusz Ahenobarbus był prawdopodobnie odpowiedzialny tylko za odbudowę istniejącego już przybytku. Badacze nie są jednak zgodni, co do tego, który z przedstawicieli gens Domitia zrealizował to zadanie. Najczęściej sugerowane są dwie możliwości. W pierwszym przypadku renowację świątyni przypisuje się Gnejuszowi Domicjuszowi Ahenobarbusowi, konsulowi roku 122 p.n.e., biorącemu w latach 130-129 p.n.e. czynny udział w kampanii przeciwko Aristonikosowi ${ }^{58}$. $\mathrm{W}$ drugim zaś jego imiennikowi, konsulowi roku 32 p.n.e., który dowodząc republikańską flotą w 42 r. p.n.e. pokonał Domicjusza Kalwinusa ${ }^{59}$. Odnalezione pozostałości wydają się sugerować pierwszą możliwość, bowiem podczas prac archeologicznych natrafiono na wiele elementów wykonanych z marmuru pentelickiego, który był wykorzystywany $\mathrm{w}$ Rzymie od połowy II w. p.n.e. aż do czasów Juliusza Cezara, kiedy to zaczęto korzystać z kamieniołomu w Luni ${ }^{60}$.

Obecnie za sprawą badań archeologicznych wiemy, że przybytek ten znajdował się przy północnej krawędzi Circus Flaminius, a nie, jak wcześniej

55 Tucci 1997: 25. Znane są natomiast inne fundacje tego wodza. Wzniósł on bowiem na Kapitolu kolumnę ozdobioną dziobami okrętów, zob. Liv. 42. 20. 1.

56 Inscr. Ital. 13. 2: 93, 99. Fasti Fratrum Arvalium wymienia z kolei świątynię Neptuna pod datą dwudziestego trzeciego września i lokalizuje ją in campo. Obecnie już wiemy, że przybytek ten należy łączyć nie z republikańską aedes, tylko z tzw. Basilica Neptuni, którą w roku 25 p.n.e. wzniósł na Polu Marsowym Marek Agryppa, zob. Inscr. Ital. 13. 2; 34, Ziółkowski 1992:101, 117-118.

57 Tucci 1997: 21.

58 Broughton 1951: 505; Coarelli 1997: 414-415.

59 App. BC. 4. 115 ; Plut. Brut. 47 ; Cass. Dio, 47. 47. 4; Wiseman 1974: 7.

60 Bernard 2010: 35-54. sądzono, przy zachodniej, gdzie identyfikowano go przez długie lata z pozostałościami odnalezionymi przy kościele S. Salvatore in Campo ${ }^{61}$. Elementy świątyni Neptuna zostały bowiem odkryte na rogu Via del Portico di Ottavia 1-2 i Piazza Castaguti, w piwnicy Casa di Lorenzo Manlio62.

Oprócz pomniejszych fragmentów architektonicznych, takich jak chociażby marmurowe dachówki, natrafiono w tym miejscu na pozostałości podium $\mathrm{z}$ trawertynu o wymiarach $8,50 \times 5,65 \mathrm{x}$ $1,75 \mathrm{~m}$. Część podstawy wykonanej z tufu w technice opus quadratum odnaleziono z kolei na wysokości Tempietto del Carmelo. Co w połączeniu $\mathrm{z}$ fragmentami kolumn oraz ich głowicami wmurowanymi w ścianę piwnicy Casa di Lorenzo Manlio, stanowi świadectwo obecności świątyni w tym miejscu $^{63}$.

Aedes Neptuni została przedstawiona także na monecie Gnejusza Domicjusza Ahenobarbusa, który po zwycięstwie nad Kalwinusem został okrzyknięty przez swoich żołnierzy imperatorem. Na wybitym w latach 41-38 p.n.e. aureusie świątynię zaprezentowano jako tetrastylos zbudowany na wysokim podium ${ }^{64}$.

Jednak, jak wykazały ostatnie badania archeologiczne, aedes była prawdopodobnie większa i miała sześć kolumn od frontu ${ }^{65}$. Nie sugeruje to jednak, że na monecie przedstawiono inną świątynię, bowiem wizerunki umieszczane na numizmatach nie miały oddawać dokładnego wyglądu poszczególnych budowli, dlatego redukcja kolumn była w tym wypadku normalną procedurą, którą stosowali rzymscy rytownicy. Dla Ahenobarbusa ważniejsza była natomiast prezentacja własnego sukcesu, stąd na monecie nad świątynią umieszczono legendę - Nept. Gn. Domitius. L.F. Imp. Monument ten został również ukazany na reliefie z Ostii, gdzie stoi przy przybytku Herkulesa (badacze nie są jednak zgodni czy jest to aedes Herculis Custodis ${ }^{66}$

61 F. Coarelli 1968 b: 302-368; Coarelli 2008: 274.

62 Tucci 1997: 21.

63 Tucci 1997: 21; Bernard 2010: 35-36.

64 RRC 527. Wódz wybił jeszcze denary z przedstawieniem dziobu okrętu oraz tropajonu, zob. RRC 519.

65 Badania archeologiczne $\mathrm{z}$ roku 2001 jak do tej pory nie zostały opublikowane.

66 Ziółkowski 1992: 53; Zevi 1993: 661-708. Według części badaczy również ta świątynia została ufundowana w III w. p.n.e. za pośrednictwem manubiae. Ziółkowski zasugerował, że aedes powstała w tym samym czasie, co Circus Flaminius i była ślubowana podczas kampanii Gnejusza Flaminiusza Neposa w Galii Przedalpejskiej w roku 223 p.n.e. Zevi z kolei stara się połączyć monument z osobą Marka Minucjusza Rufusa, 
czy Herculis Musarum $)^{67}$. Niestety fragmentaryczność tej sceny nie pozwala na wyciągnięcie jednoznacznych wniosków na temat wyglądu przybytku.

Niewykluczone, że świątynię Neptuna flankował także portyk, który w połowie II w. p.n.e. ufundował na Polu Marsowym Gnejusz Oktawiusz, dowódca floty podczas wojny z Perseuszem ${ }^{6}$. Jednak brak pozostałości archeologicznych nie pozwala na określenie jego formy, a także korelacji z poszczególnymi przybytkami znajdującymi się w tej części Miasta.

\section{3. Świątynia Pietas (Pietas, aedes) ${ }^{69}$}

Przybytek poświęcony personifikacji Pietas ślubował wznieść w roku 191 p.n.e. Maniusz Acyliusz Glabrion ${ }^{70}$. Podobnie jak w przypadku świątyni Bellony, wódz obiecał tę fundację w czasie bitwy: is erat, qui ipse eam aedem uouerat, quo die cum rege Antiocho ad Thermopylas depugnasset, locaueratque idem ex senatus consulto ${ }^{71}$. Starcie to przyniosło Rzymianom dużą liczbę łupów. Do tej zdobyczy doliczyć należy także przedmioty zagarnięte $\mathrm{z}$ wielu greckich miast, które zaprezentowano podczas triumfu Glabriona ${ }^{72}$. Dux część tych łupów zarezerwował zapewne na budowę rzeczonego monumentu. Według Zonarasa bowiem spory procent manubiae przypadł w jego udziale $^{73}$.

który w roku 217 p.n.e. jako magister equitum walczył w Kampanii i po wojnie poświęcił w Rzymie wota dla Herkulesa, zob. CIL $1^{2}$. 607. Niestety są to tylko hipotezy. Jedyną pewną informacją na temat przybytku jest przekaz Owidiusza, który wspomina Sullę jako ewentualnego fundatora. Jeśli przyjmiemy taką możliwość to aedes wzniesiono po zasięgnięciu opinii z ksiąg sybillińskich, zob. Ov. Fast. 6. 208; Coarell 1997: 498. Brak pozostałości archeologicznych tej budowli nie pozwala na określenie jej pewnej lokalizacji. Najczęściej sugerowane są: północno - zachodnia strona cyrku bądź jego południowo-zachodnia krawędź.

67 Coarelli 1997: 401; Tucci 2000: 279-290.

68 Plin. NH. 34. 13; Vell. Pat. 2. 1. 1; Fest. 188L; Tucci 1997: 33

69 Ciancio Rossetto 1999: 86.

70 Liv. 40. 34. 4. Na temat działań wodza podczas kampanii, zob. Broughton 1951: 352.

71 Liv. 40. 34. 4-6.

72 ILLRP 321a; Liv. 36. 24. 6; Liv. 37. 5. 3; Liv. 37. 46. 1-2. Grabież Heraklei i Skarfei poświadczona jest epigraficznie na bazach odnalezionych w rzymskiej koloni w Luni. Oprócz tych dwóch miast Rzymianie złupili także Lamię.

73 Cass. Dio - Zonar. 9. 19; Shatzman 1975: 241.
Prace nad przybytkiem rozpoczęły się w roku 190 p.n.e. (locaueratque ex senatus consulto). Za jego dedykację nie odpowiadał jednak wódz, tylko jego syn, który specjalnie w tym celu został mianowany duumwirem (duumviri aedi dedicandae) w roku 181 p.n.e. ${ }^{74}$ Wewnątrz aedes ustawił on ponadto pozłacany posąg konny swojego ojca ${ }^{75}$.

Dies natalis świątyni wymieniany jest w rzymskich kalendarzach zarówno pod datą trzynastego listopada jak i pierwszego grudnia ${ }^{76}$. Badacze nie są jednak zgodni, który dzień odnosił się do dedykacji Glabriona. Coarelli uważa, że był to pierwszy grudnia, gdyż Fasti Antiates Maiores, podające termin listopadowy jest uszkodzone i równocześnie fragment ten mógł odnosić się do kultu Felicitas ${ }^{77}$. Lenna Pietilä-Castrén uważa z kolei, że dies natalis wypadał w listopadzie, pierwszy grudnia odnosił się zaś do ponownej dedykacji przybytku po jego odbudowie $^{78}$. Wiemy skądinąd, że przybytek był kilkukrotnie remontowany, pierwszy raz prawdopodobnie w 150 r. p.n.e., następnie po roku 91 p.n.e., kiedy to ucierpiał na skutek uderzenia piorunem. $\mathrm{W}$ drugiej połowie I w. p.n.e. został on natomiast ostatecznie rozebrany na rozkaz Juliusza Cezara, który szykował teren pod nowy teatr ${ }^{79}$.

Według Pliniusza Starszego świątynia stała w miejscu późniejszego Teatru Marcellusa ( $u b i$ nunc Marcelli theatrum est ${ }^{80}$. Liwiusz lokalizuje przybytek in foro Holitorio, Juliusz Obsekwens z kolei in Circo Flaminio ${ }^{81}$. Wszystkie te przekazy sugerują, że aedes znajdowała się pomiędzy wschodnią częścią circus oraz zachodnią forum. Taką lokalizację wydają się potwierdzać ostatnie badania archeologiczne. Podczas prac prowadzonych w połowie lat 90 . XX w. pomiędzy kościołem

74 Liv. 40. 34. 4; Bloy 1999: 49-61. Według części badaczy w roku 181 p.n.e. wódz już nie żył, dlatego za dedykację świątyni odpowiadał jego syn. Bloy z kolei uważa, że Glabrion żył jeszcze w tym okresie, a wybór jego syna na duumwira miał pomóc mu w rozpoczęciu kariery politycznej.

75 Val. Max. 2. 5. 1.

76 Inscr. Ital. 13. 2 : 530, 533. Według Fasti Antiates Maiores świątynia została poświęcona trzynastego listopada, w Fasti Amiternini, wymieniona została z kolei pod datą pierwszego grudnia.

77 Coarelli 1997: 448.

78 Pietilä-Castrén 1987: 89.

79 Plin. NH. 7. 121; Obs. 54; Cass. Dio. 43. 49. 3. Kasjusz Dion wspomina, że podczas rozbiórki świątyń Cezar zachował dla siebie znalezione w przybytkach depozyty, niszcząc ponadto wiele posągów znajdujących się w tej części miasta.

80 Plin. NH. 7. 121; Pietilä-Castrén 1987: 88-89.

81 Liv. 40. 34. 6; Obs. 54 
S. Nicola in Carcere a Teatrem Marcellusa odkryto pozostałości platformy wykonanej z tufu wulkanicznego z Grotta Oscura i Monteverde, którą badacze automatycznie zidentyfikowali jako republikańską świątynię Pietas. Podium to zostało ustawione w ten sam sposób, co pozostałe trzy przybytki zlokalizowane w obrębie kościoła S. Nicola in Carcere (Spes, Junony i Janusa), jednak jest ono wysunięte bardziej w kierunku północno - zachodnim ${ }^{82}$.

Coarelli uważa ponadto, że po rozebraniu republikańskiej świątyni Pietas z rozkazu Cezara, odbudowano ją jako sacellum za sceną Teatru Marcellusa w czasach Augusta. Według archeologa kapliczkę tę przedstawiono na fragmencie FUR (31qrs), gdzie widać dwa małe kwadraty, z których jeden ma reprezentować przybytek Pietas drugi Diany ${ }^{83}$. Interpretacja ta wzbudza jednak szereg wątpliwości, gdyż część badaczy sugeruje, iż rzeczone kwadraty mogą symbolizować bazy pod posągi ${ }^{84}$.

Niemniej jednak za sprawą badań archeologicznych możemy ostatecznie odrzucić koncepcję Lawrenca Richardsona jr., który uważał, że przybytek Pietas należy identyfikować z pozostałościami znajdującymi się przy północnej ścianie kościoła S. Nicola in Carcere $^{85}$. Jak sugeruje bowiem lokalizacja odkrytego podium, świątynia ta znajdowała się bliżej Circus Flaminius, niż trzy pozostałe przybytki ufundowane w obrębie Forum Holitorium.

\section{4. Świątynia Herkulesa przewodnika Muz (Hercules Musarum, aedes) ${ }^{86}$}

Przekazy dotyczące świątyni Herculis Musarum nie są jednoznaczne. O ile za sprawą rekonstrukcji fragmentów FUR (31bb, 31 eeff, 31hh) kwestia lokalizacji i wyglądu monumentu jest jasna, to już w przypadku poszczególnych etapów budowy pojawia się wiele znaków zapytania.

Analizując źródła napotykamy bowiem na szereg sprzeczności. Najobszerniejszy przekaz na temat budowy tej świątyni pochodzi z III w. n.e. $i$ jest autorstwa retora Eumeniusza, który zaznaczył, że za jej budowę odpowiedzialny był wódz Marek Fulwiusz Nobilior, który prowadząc działania militarne w Grecji w roku 189 p.n.e. dowiedział się o kulcie Herkulesa z przydomkiem Musagetes,

\footnotetext{
82 Ciancio Rossetto 1999: 86.

83 Coarelli 1997: 451.

44 Viscogliosi 1995: 14.

85 Richardson jr. 1992: 290.

86 Viscogliosi 1996a : 17-19.
}

dlatego zabrał ze zdobytej Ambrakii posagi dziewięciu Muz, które po powrocie do Rzymu ustawił wspólnie ze statuą herosa. Retor lokalizuje świątynię in circo Flaminio, co jest zgodne z zachowanymi fragmentami FUR. Uważa on ponadto, że przybytek został ufundowany z pieniędzy, którymi Nobilior dysponował gdy był cenzorem $(179 \text { r. p.n.e. })^{87}$.

W tym samym tonie utrzymany jest passus Cycerona, który zaznaczył, że Nobilior prowadząc w Grecji kampanie przeciwko Etolom, po powrocie do Rzymu poświęcił łupy Muzom ${ }^{88}$. Arpinata nie informuje jednak czy wódz ufundował świątynię. Podobnie jak Serwiusz. Komentator dzieł Wergiliusza zaznaczył tylko, że $d u x$ przeniósł brązową kapliczkę Muz do przybytku Herkulesa, która od tego czasu była znana jako aedes Herculis et Musarum $^{89}$

O tym, że część łupów została poświęcona w świątyni, wiemy ponadto za sprawą źródeł epigraficznych. W połowie XIX w. została odnaleziona bowiem przy Via S. Ambrogio inskrypcja, umieszczona na bazie, na której mógł stać jeden z zagrabionych z Ambrakii posągów (M. Folvios M.f. / Ser.n. Nobilior / Cos. Ambracia / Cepit $)^{90}$.

Nie jest jednak pewne czy cały przybytek została wzniesiony ex manubiis . Cyceron mimo, że wspomina o wykorzystaniu manubiae, to bezpośrednio nie odnosi się do świątyni, tylko do jej dekoracji. Eumeniusz z kolei zaznacza, że wódz wykorzystał na ten cel pecunia censoria. Jednak Liwiusz, który skrupulatnie wylicza poszczególne projekty Nobilior - ufundowane podczas cenzury - nie wspomina o budowie przybytku Herculis Musarum. Historyk ten zaznacza tylko, że zdobywca Ambrakii wzniósł w roku 179 p.n.e. portyk, który znajdował się przy świątyni Herkulesa ${ }^{91}$.

Swetoniusz natomiast uważa, że aedes została zbudowana dopiero przez Lucjusza Filippusa z jego manubiae, zdobytych podczas kampanii w Hiszpanii (35-33 r. p.n.e. $)^{92}$. Zważywszy na fakt, iż znana jest inskrypcja Nobiliora poświadczająca grabieżAmbrakii, a także przekazy numizmatyczne,

87 Eumen. Panegry. 7. 3. Na temat działań wodza podczas kampanii, zob. Broughton 1951: 360.

88 Cic. Pro Arch. 27 (iam vero ille, qui cum Aetolis Ennio comite bellavit, Fulvius non dubitavit Martis manubias Musis consecrare [...]).

89 Serv. Aen. 1. 18. Kapliczka ta była przeniesiona $\mathrm{z}$ przybytku Honos et Virtus, który znajdował się przy Porta Capena.

90 CIL 6. 1307.

91 Liv. 40. 51. 6.

92 Suet. Aug. 29. 5. 
które wspominają o kulcie Herkulesa przewodnika Muz już w roku 56 p.n.e., ostatni z przekazów interpretowany jest przez większość badaczy inaczej $^{93}$. Uważają oni, że Filippus odbudował tylko istniejącą już świątynię, dobudowując przy niej także okazały portyk ${ }^{94}$.

Opierając się jednak na przekazie Liwiusza oraz Serwiusza część uczonych sądzi, że Nobilior ufundował tylko portyk przy istniejącej już w tej części Rzymu świątyni Herculis Custodis, która po przeniesieniu w jej obszar brązowej kapliczki Muz znana była jako aedes Herculis et Musarum ${ }^{95}$. Koncepcja ta ma jednak słaby punkt, bowiem w poszczególnych Fasti monumenty te wzmiankowane są pod różnymi datami, co sugeruje, że były to dwie niezależne od siebie świątynie ${ }^{96}$.

W takim wypadku należy przyjąć, jako najbardziej prawdopodobną możliwość, że za budowę przybytku Herculis Musarum odpowiadał Marek Fulwiusz Nobilior, który ufundował świątynię in circo Flaminio, w miejscu skrzyżowania współczesnej Via S. Ambrogio i Via del Portico di Ottavia. Prace rozpoczęły się być może po triumfie wodza de Aetoleis et Caphallenia z roku 187 p.n.e., podczas którego zaprezentowano wiele łupów wojennych ${ }^{97}$.

Niestety poszczególne etapy budowy tego monumentu nie są znane. Choć Pietilä-Castrén sugeruje, że locatio mogło mieć miejsce w roku 186 p.n.e., kiedy Nobilior zorganizował igrzyska ku czci Jowisza, żadne źródła tego nie potwierdzają. Podobnie jak daty dedicatio, bowiem Eumeniusz wspomina tylko o formie finansowania budowy przybytku ${ }^{98}$. Niemniej jednak świątynia powstała zapewne w latach 187-179 p.n.e. i jeśli

93 RRC 410.

94 Ov. Fast. 6. 797-812; Plin. NH. 35. 66; Coarelli 1997: 457; Weigel 1998: 132. Coarelli zaznaczył, że brak wzmianki u Liwiusza na temat fundacji świątyni przez Nobiliora może wynikać z faktu, że autor ten chciał przypodobać się Augustowi, w którego Żywocie autorstwa Swetoniusz, czytamy, że syn ojczyma princepsa, Lucjusz Filippus był odpowiedzialny za budowę przybytku Herkulesa przewodnika Muz. Wyjaśnienie to nie przekonuje, zważywszy że Liwiusz dość skrupulatnie wylicza inne budowle ufundowane przez Nobiliora.

95 Castagnoli 1961: 604-610.

96 Ov. Fast. 6. 209; Ov. Fast. 6. 797-812; Inscr. Ital. 13. 2: 465; Inscr. Ital. 13. 2: 475. W przypadku świątyni Herculis Custodis - dies natalis przypadał czwartego czerwca. Herculis Musarum zaś trzydziestego czerwca.

97 Liv. 39. 5. 5-6; Plin. NH. 35. 66.

98 Pietilä-Castrén 1987: 100-101. w całości nie była wzniesiona z łupów wojennych, to za sprawą zachowanej inskrypcji oraz passusu z mowy Cycerona wiemy, że w jej wnętrzu znajdowało się sporo manubiae, które Nobilior splądrował w Grecji99.

Dzięki poszczególnym fragmentom FUR oraz badaniom archeologicznym możemy obecnie zrekonstruować wygląd świątyni, której forma była niezwykle oryginalna jak na początek II w. p.n.e. Na rzeczonym planie miasta przybytek Herkulesa przewodnika Muz został przedstawiony wewnątrz portyku, który w drugiej połowie I w. p.n.e. ufundował wspominany już Lucjusz Filippus ${ }^{100}$.

Aedes wzniesiono na wysokim podium (około 3 m wysokości) o wymiarach 48 × $21 \mathrm{~m}$. Kształt podstawy przypominał czworobok $\mathrm{z}$ dwoma wysuniętymi $\mathrm{w}$ kierunku południowym ramionami, w których prawdopodobnie umieszczono kopie fasti ${ }^{101}$. W centralnej części podium stała cela $\mathrm{w}$ formie tolosu, do której prowadziły schody oraz pronaos z czterema kolumnami. Szacuje się, że średnica tego pomieszczenia miała około $11 \mathrm{~m}$, podobnie jak eksedry znajdującej się za przybytkiem (przestrzeń ta była zapewne wykorzystywana podczas spotkań poetów) ${ }^{102}$. Coarelli uważa ponadto, że kwadraty, które zostały zaznaczone za eksedrą (widoczne na fragmencie FUR (31eeff)), to bazy pod posągi Muz, które z Grecji przywiózł Nobilior. Kwestia ta jest jednak szeroko dyskutowana, gdyż inni uczeni sądzą, że w ten sposób przedstawiono na planie drzewa, które znajdowały się za świątynią ${ }^{103}$. Nie można wykluczyć więc możliwości, że statuy były ustawione w niszach, które znajdowały się po wewnętrznej jak i zewnętrznej stronie podium lub po prostu $\mathrm{w}$ samej celli. Pewne pozostałości wspomnianej eksedry udało się odkryć archeologom w roku 1983 w obrębie kościoła S. Ambrogio della Massima, gdzie odsłonięto kilka kamiennych bloków z tufu Cappellaccio ${ }^{104}$. $\mathrm{Na}$ placu przed świątynią, który był ograniczony $\mathrm{z}$ dwóch stron przez podstawę z niszami, stał z kolei okrągły ołtarz bądź brązowa kapliczka Muz ${ }^{105}$.

99 Shatzman 1972: 182.

100 Coarelli 1997: 457.

101 Varro. Ling. 6. 33; Macrob. Sat. 1. 12. 6. Źródła niestety nie podają jaki rodzaj fasti został umieszczony w świątyni.

102 Plin. NH. 34. 19; L. Pietilä-Castrén 1987: 102.

103 Coarelli 1997: 482; Bravi 2014: 36.

104 Gianfrotta 1985: 376-384.

105 Viscogliosi 1996a: 19. 


\section{5. Świątynia Junony Królowej \\ (Iuno Regina, aedes) \\ i świątynia Diany (Diana, aedes) $)^{106}$}

Świątynię Junony Królowej i Diany wyodrębniono w jednym punkcie, gdyż były one wzniesione przez tego samego wodza. Za ich budowę odpowiadał Marek Emiliusz Lepidus, który w roku 187 p.n.e. ślubował rzeczone monumenty podczas kampanii w Ligurii ${ }^{107}$. Dedykowano je in circo Flaminio osiem lat później, kiedy Lepidus sprawował z Nobiliorem urzą cenzora ${ }^{108}$. Zarówno $\mathrm{w}$ pierwszym jak i w drugim przypadku ich dies natalis wypadał dwudziestego trzeciego grudnia ${ }^{109}$.

Niestety, żadne przekazy nie wspominają o tym, w jaki sposób wódz sfinansował pracę nad budową świątyń. Zważywszy jednak na małą liczbę zdobytych przez niego łupów prawdopodobne jest, że fundacje wzniesiono $\mathrm{z}$ dwóch źródeł: $m a-$ nubiae oraz pieniędzy $\mathrm{z}$ aerarium ${ }^{110}$. Za pośrednictwem Juliusza Obsekwensa wiemy bowiem, że w obrębie przybytku Junony zostały umieszczone łupy wojenne w postaci tarcz liguryjskich wojowników ${ }^{111}$. Jednak, aby zorganizować igrzyska z okazji dedykacji przybytków, Lepidus zwrócił się do Senatu o przyznanie mu pieniędzy ${ }^{112}$.

W przypadku świątyni Junony jej dokładną lokalizację możemy określić za sprawą zachowanego fragmentu FUR (31bb). Aedes znajdowała się przy północnej krawędzi Cyrku Flaminiusza, stąd w Fasti Antiates Maiores jest ona usytuowana in campo, zaś w Fasti Palatii Urbinatis - ad circum, a więc $\mathrm{w}$ obszarach bezpośrednio z sobą graniczących ${ }^{113}$.

Przybytek był kilkukrotnie remontowany. Pierwszy raz prawdopodobnie po roku 156 p.n.e., kiedy ucierpiał podczas pożaru, który, jak podaje Juliusz Obsekwens, zniszczył część cyrku pomiędzy świątynią Junony i Fortuny ${ }^{114}$. Następnie, być może w 134 r. p.n.e., kiedy został trafiony przez piorun $^{115}$. Niewykluczone jednak, że to dopiero

106 Viscogliosi 1996b; 126-128; Viscogliosi 1995: 14.

107 Liv. 39. 2. 8-11. Na temat działań wodza podczas kampanii, zob. Broughton 1951: 367.

108 Liv. 40. 52. 1.

109 Inscr. ltal. 13. 2: 25, 544-545.

110 Shatzman 1975: 242.

111 Obs. 16; Weigel 1998: 133.

112 Liv. 40. 52. 1.

113 Inscr. Ital. 13. 2: 512, 544. Po odbudowie przybytku w okresie Augusta dies natalis przypadał w dzień urodzin princepsa, tzn. dwudziestego trzeciego września.

114 Obs. 16; Obs. 25.

115 Obs. 16; Coarelli 1997: 487.
Kwintus Cecyliusz Metellus (najpóźniej do końca 131 r. p.n.e.) wyremontował świątynię, gdy wzniósł obok niej przybytek Jowisza Statora oraz portyk $^{116}$. Kolejne rekonstrukcje przechodziła ona w czasach Augusta oraz Septymiusza Sewera ${ }^{117}$. Prawdopodobnie również dopiero po jej odbudowie w połowie II w. p.n.e. bądź pod koniec I w. p.n.e. do świątyni trafiło wiele dzieł sztuki, pośród których znajdowały się dwa posągi Junony; jeden autorstwa Dionizjosa, drugi Poliklesa. Ponadto statua Wenus dłuta Filiskosa czy Diana i Eskulap, które wyszły spod ręki Kefizodotosa. Według Magrit Pape część tej kolekcji mogły stanowić łupy, które Metellus zdobył podczas kampanii w Macedonii ${ }^{118}$.

Dzięki badaniom archeologicznym wiemy, że wygląd aedes przedstawiony na FUR jest nieprecyzyjny, gdyż w III w. n.e. świątynia miała zapewne już sześć jońskich kolumn od frontu, a nie, jak ukazano na planie, cztery. Niewykluczone jednak, że pierwotnie została ona zaplanowana jako tetrastylos. Ponadto badaczom udało się ustalić, iż podłoga obszernej celli, w której stał posąg bogini znajdowała się kilka stopni wyżej niż pronaos ${ }^{119}$.

Określenie lokalizacji drugiego monumentu ufundowanego przez Lepidusa, a więc świątyni Diany jest zdecydowanie bardziej problematyczne. Opiera się ono głównie na spekulacjach poszczególnych badaczy, którzy uważają, że musiała ona znajdować się nieopodal przybytku Junony. Na tej podstawie Coarelli zasugerowat, iż monument ten stał na miejscu późniejszego Teatru Marcellusa, gdzie podobnie jak przybytek Pietas został rozebrany i odbudowany przez Augusta. Archeolog uważa też, że świątynię przedstawiono także na wybitym pomiędzy 29-27 r. p.n.e. aureusie ${ }^{120}$, oraz na FUR (31qrs). Badacz łączy ją w tym wypadku $\mathrm{z}$ jednym $\mathrm{z}$ dwóch kwadratów przedstawionych za sceną teatru ${ }^{121}$

Jednak materiał, na którym swoją koncepcję opiera Coarelli jest niejednoznaczny. Zaczynając od monety należy mieć na uwadze, że pomimo tego, iż na jej awersie została przedstawiona Diana, to nie można wyciągać jednoznacznych wniosków, że na rewersie znajdowała się świątynia dedykowana

\footnotetext{
116 Vell. Pat. 1. 11. 13.

117 Suet. Aug. 29. 4; Cass. Dio, 49. 43. 8 ; CIL 6. 1034.

118 Plin. NH. 36. 24 ; Plin. NH. 36. 35; Pape 1975:16.

119 Viscogliosi 1996b: 127. Fragmenty kolumn odnalezione w piwnicach domów przy Via di S. Angelo in Pescheria, prawdopodobnie należą do świątyni Junony.

120 RIC $1^{2} .273$

121 Coarelli 1997: 451.
} 
tej bogini. Nawet jeśli przyjmiemy, iż tak było, to równie dobrze emitent mógł przedstawić przybytek wzniesiony na Awentynie, który odbudował dowódca floty Augusta, Lucjusz Kornificjusz, lub, co bardziej prawdopodobne, sycylijską świątynię Diany znajdująca się nieopodal Naulochos, gdzie Marek Agryppa pokonał Sekstusa Pompejusza ${ }^{122}$.

Również kwadraty przedstawione na FUR, wcale nie muszą przedstawiać świątyni. Jak wspomniałem już przy okazji opisu przybytku Pietas, mogą one symbolizować m.in. bazy pod monumentalne posągi ${ }^{123}$. Ponadto fakt, że żaden z oficjalnych kalendarzy z okresu pryncypatu nie informuje o świątyni Diany z Cyrku Flaminiusza sprawia, że koncepcja Coarellego budzi sporo wątpliwości.

Dlatego według części badaczy monument ten mógł znajdować się przy północnej krawędzi cyrku, obok świątyni Junony, gdzie spłonął w roku 156 p.n.e. Na jego miejscu w późniejszym okresie ufundowano m.in. porticus Metelli, czy porticus Philippi $^{124}$. Przy obecnym stanie badań i braku źródeł archeologicznych nie można wykluczyć takiej ewentualności.

\section{6. Świątynia Jowisza Statora (Iuppiter Stator, aedes) $^{125}$}

Przy północnej krawędzi Cyrku Flaminiusza znajdowała się także świątynia Jowisza, określana w źródłach jako Metelli Iovis Statoris lub Iovi Metellinae $^{126}$. Przybytek ten wspólnie z portykiem ufundował Kwintus Cecyliusz Metellus, który podczas przypadającej na rok 148 p.n.e. kampanii w Macedonii zgromadził sporą ilość łupów ${ }^{127}$.

122 Suet. Aug. 29; Gurval 1998: 57-58. Na tympanonie świątyni została bowiem przedstawiona tzw. trinacria - symbol Sycylii.

123 Viscogliosi 1995: 14.

124 Wiseman 1976: 47; Pietilä-Castrén 1987:104-105.

125 Viscogliosi 1996c: 157-159.

126 Vell. Pat. 1. 11. 5; Vitr. 3. 2. 5; Plin. NH. 36. 40; Fest. 496; Pietilä-Castrén 1987: 132, contra Boyd 1953: 152 - 159. Boyd uważał natomiast, że wódz ufundował tylko portyk przy istniejących już świątyniach. Według tego autora przybytek Jowisza był również starszy niż Junony, ponieważ znajdował się bliżej miasta. Jednak w świetle passusu Wellejusza Paterkulusa hipoteza ta jest niedorzeczna. Historyk ten pisze bowiem wyraźnie, że Metellus ufundował świątynię (Metellus idem primus omnium Romae aedem [...]).

127 Liv. Per. 52; Val. Max. 7. 5. 4; Eutr. 4. 14; Shatzman $1975 ; 245$. Na temat poczynań wodza podczas
W tym także dzieła sztuki, które umieszczono w obrębie owych monumentów ${ }^{128}$.

Niestety, przy obecnym stanie źródeł nie możemy określić dokładnie, w którym momencie wódz ślubował świątynię. Prawdopodobnie uczynił to podczas bitwy przeciwko Andriskosowi, gdy zapobiegł ucieczce własnej kawalerii ${ }^{129}$. Również w przypadku locatio i dedicatio nie posiadamy żadnych konkretnych informacji. Część badaczy przypuszcza, że do rozpoczęcia budowy mogło dojść podczas przypadającego na rok 143 p.n.e. konsulatu Metellusa, a do jej dedykacji w roku 131 p.n.e., kiedy został on wybrany cenzorem ${ }^{130}$. Wiemy natomiast, że dies natalis przybytku wypadał piątego września, natomiast po przebudowie Portyku Metellusa przez Augusta oraz dwóch znajdujących się wewnątrz niego świątyń (tj. Jowisza Statora i Junony Królowej) dedykowano ją ponownie w dzień urodzin princepsa - dwudziestego trzeciego września ${ }^{131}$.

$\mathrm{Za}$ jej budowę odpowiadał grecki architekt Hermodoros ${ }^{132}$ i, jak zaznaczył Wellejusz Paterkulus, był to pierwszy przybytek wzniesiony $\mathrm{w}$ Rzymie $\mathrm{z}$ marmuru ${ }^{133}$. Uczeni w różny sposób podchodzą jednak do informacji na temat wykorzystania tego rodzaju kamienia. Według Pierra Grosa cała świątynia została zbudowana $\mathrm{z}$ tego materiału. Gwyn Morgan uważa jednak, że podczas prac wykorzystano tylko marmurowe płyty, którymi pokryto podstawę i ściany z tufu wulkanicznego ${ }^{134}$. Niestety żadne pozostałości tej fazy budowy nie zostały odkryte, co sprawia, że dyskusja ta pozostaje nierozstrzygnięta ${ }^{135}$.

Wygląd świątyni oraz jej dokładną lokalizację możemy przybliżyć dzięki zachowanym przekazom narracyjnym, a także badaniom archeologicznym i rekonstrukcji fragmentów FUR

kampanii zob. Broughton 1951: 461.

128 Cic. Verr. 4. 126; Vell. Pat. 1. 11. 5.

129 Cass. Dio - Zonar. 9. 28; Pietilä-Castrén 1987: 129.

130 Gwyn Morgan 1971: 486; Coarelli 1997: 489. Coarelli uważa jednak, że świątynię dedykowano już w roku 143 p.n.e.

131 Inscr. Ital. 13. 2: 508, 512.

132 Vitr. 3. 2. 5.

133 Vell. Pat. 1. 11. 3-5 (Metellus idem primus omnium Romae aedem ex marmore in iis ipsis monumentis molitus huius vel magnificentiae vel luxuriae princeps fuit $[\ldots])$.

134 Gwyn Morgan 1971 : 505, Gros 1978 : 38 .

135 Pietilä-Castrén 1987: 132-133; Bernard 2010: 36. Na budowę świątyni wykorzystano prawdopodobnie marmur pentelicki, który Metellus mógł zdobyć podczas swojej kampanii wojennej. 
(31ggz). W Fasti Palatii Urbinatis czytamy Iovi Statori ad circum Flaminium ${ }^{136}$. Przybytek stał po wschodniej stronie świątyni Junony Królowej i, jak zaznaczył Witruwiusz, był to heksastylos z jedenastoma kolumnami na dłuższych bokach ${ }^{137}$. W okresie Augusta został on jednak przebudowany jako peripteros sine postico (widać to $\mathrm{m}$. in. na FUR 31u i 31ggz). Zmiana formy mogła wynikać z dobudowania za monumentem tzw. schola Octaviae ${ }^{138}$. Według Pliniusza Starszego za restaurację aedes odpowiadali spartańscy architekci - Sauras i Batrachos, którzy umieścili na bazach kolumn signa w postaci jaszczurki i żaby ( $\sigma \alpha v ́ \rho \alpha$

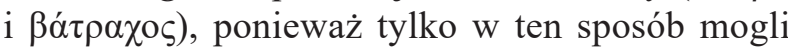
oni zaznaczyć swój udział w przebudowie świątyni ${ }^{139}$. Badacze nie są jednak zgodni, co do autentyczności tego przekazu uważając, że równie dobrze Pliniusz Starszy stworzył ajtiologiczną historię do znajdujących się na bazach znaków ${ }^{140}$. Świątynia została przebudowana także w okresie Sewerów, a pozostałości tej fazy budowy zlokalizowano pod kościołem S. Maria in Campitelli ${ }^{141}$.

Wewnątrz przybytku znajdował się posąg kultowy Jowisza autorstwa Dionizjosa i Poliklesa, a także statuy Pana i Olymposa w scenie zapasów oraz Wenus ${ }^{142}$. Niestety, Pliniusz Starszy nie informuje w jaki sposób dzieła te trafiły do Rzymu, jednak zważywszy na ilość posągów, które Metellus przywiózł po swojej kampanii, jest możliwe, że część z nich została wywieziona $\mathrm{z}$ Macedonii jako łup wojenny. Podobnie zresztą jak ustawiona w okalającym świątynię Jowisza Statora i Junony Królowej portyku, grupa macedońskich jeźdźców autorstwa Lizypa, którą wódz wywiózł z Dion ${ }^{143}$.

\section{7. Świątynia Marsa (Mars, aedes) $)^{144}$}

Działalność Hermodorosa nie ograniczyła się tylko do świątyni Jowisza Statora. Grecki architekt był również odpowiedzialny za budowę przybytku Marsa, ślubowanego przez Decymiusza

136 Inscr. Ital. 13. 2: 512.

137 Vitr. 3. 2. 5

138 Viscogliosi 1996c: 158.

139 Plin. NH. 36. 24.

140 Gwyn Morgan 1971: 491.

141 Viscogliosi 1996: 158.

142 Plin. NH. 36. $35-35$.

143 Cic. Verr. 2. 4. 126; Vell. Pat. 1. 11. 4; Plin. NH. 34. 64; Plut. Alex. 16. 8; Arr. Anab. 1. 16. 4; Pape 1975: $16,186$.

144 Zevi 1996: 227-229.
Juniusza Brutusa, prawdopodobnie w roku 138 p.n.e., gdy prowadził działania militarne w Hiszpani1 ${ }^{145}$. Monument ten został wzniesiony in circo Flaminio, a na jego budowę wykorzystano manubiae, które wódz zgromadził podczas kampanii ${ }^{146}$. Niestety, nie posiadamy żadnych informacji wspominających locatio oraz dedicatio przybytku. Prawdopodobnie została ona dedykowana po triumfie Brutusa, pomiędzy rokiem 135-130 p.n.e. ${ }^{147}$ Żaden z zachowanych rzymskich kalendarzy nie informuje bezpośrednio o dies natalis tej świątyni. Stąd część badaczy stara się łączyć kult ze wspominanym pod datą czternastego maja Marsem z przydomkiem Invictus ${ }^{148}$. Jednak są to tylko spekulacje.

Monument identyfikuje się obecnie z pozostałościami odnalezionymi przy kościele S. Salvatore in Campo, którego lokalizacja odpowiada zachodniej krawędzi Circus Flaminius. Odkryte w XIX w. elementy krepidomy, stylobatu, wykonanych $\mathrm{z}$ marmuru pentelickiego kolumn, a także zachowany fragment FUR (238b) sugerują, że świątynia miała typowo grecki charakter. Była ona pozbawiona m.in. pronaosu. Miała za to głęboką celle prowadzącą do adytonu. Na podstawie zachowanych pozostałości uważa się, że przybytek był zaplanowany jako heksastylos z jedenastoma kolumnami na dłuższych bokach. Edoardo Tortorici sądzi jednak, że monument ten został zaplanowany jako peripteros sine postico ${ }^{149}$.

Wewnątrz świątyni Brutus kazał umieścić wersy z dzieł poety Akcjusza. Stały tam także posągi Skopasa przedstawiające siedzącego Marsa oraz Wenus ${ }^{150}$. Niestety proweniencja tych dzieł nie jest znana. Fragmenty statui bogini zostały odnalezione natomiast pod koniec XIX w. przy Via degli Specchi i, jak zasugerował Tortorici, dzieło to mogło reprezentować typ Wenus z Knidos ${ }^{151}$.

145 Nep. Prisc. 17. Działania wodza w Hiszpanii, zob. Broughton 1951: 487.

146 Val Max. 8. 14. 2 (Similiter honoratus animus erga poetam Accium D. Bruti suis temporibus clari ducis extitit, cuius familiari cultu et prompta laudatione delectatus versibus templorum aditus, quae ex manubiis consecraverat, adornavit [...]).

147 Zevi 1996 : 227. Data triumfu nie jest pewna, zob. Rich 2014: 250.

148 Inscr. Ital. 13. 2: 57; Coarelli 1997: 494. Sceptycznie do łączenia tych dwóch kultów podchodzi Ziółkowski, zob. Ziółkowski 1992: 100-103.

149 Tortorici 1988: 74.

150 Cic. Pro Arch. 27; Plin. NH. 36. 26; E. Rodriguez-Almeida 1991-1992: 12-16.

151 Tortorici 1988: 74 


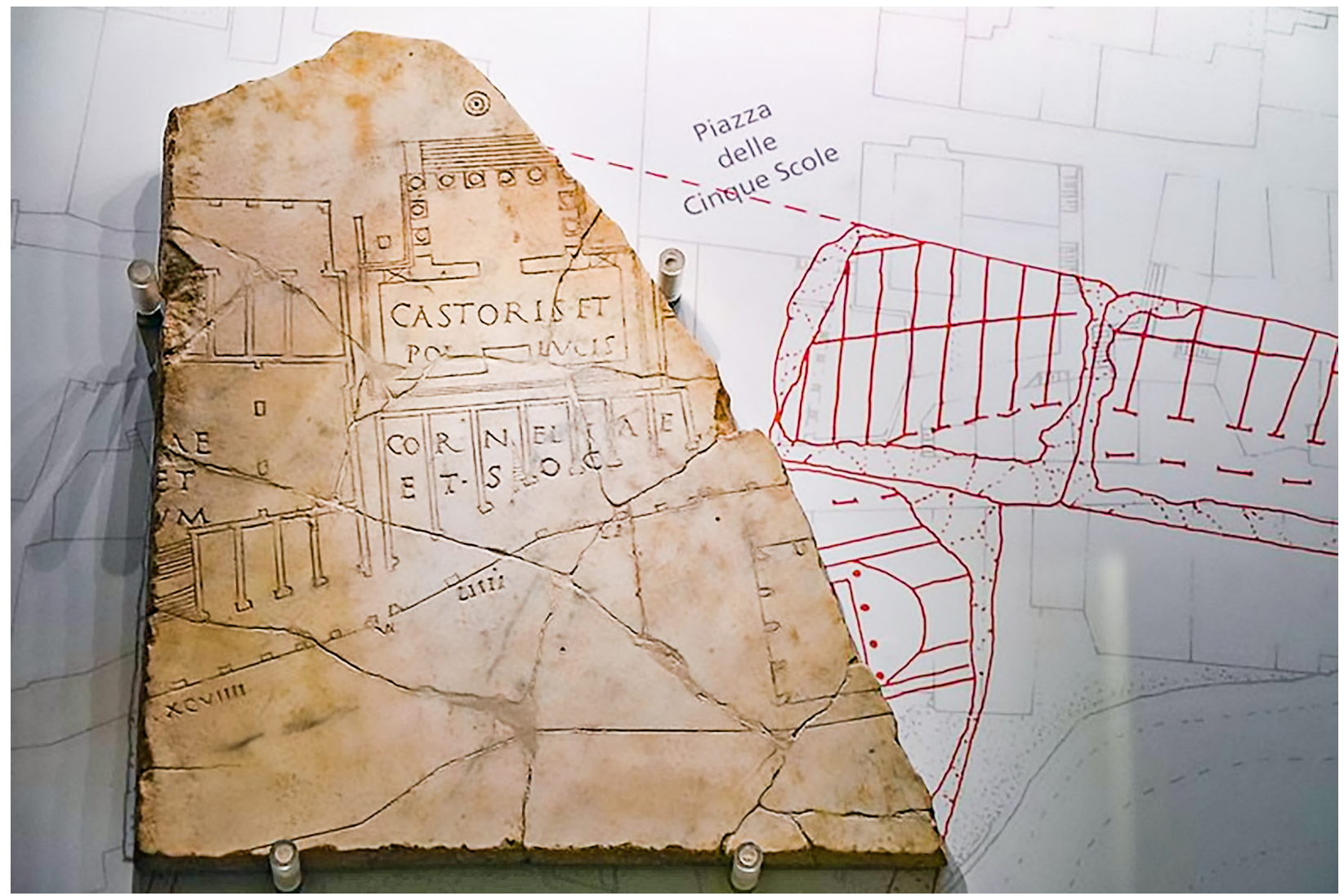

Ryc. 2. Fragment Forma Urbis Romae ze świątynią Kastora i Polluksa (wikimedia)

\section{8. Świątynia Kastora i Polluksa \\ (Castor et Pollux, aedes) ${ }^{152}$}

Na temat fundacji świątyni Kastora i Polluksa dysponujemy trzema przekazami źródłowymi. O formie architektonicznej i lokalizacji tej budowli wspomina m.in. Witruwiusz. Autor ten informuje, że znajdowała się ona in Circo Flaminio, a jej kształt był zbliżony do przybytku Vediovisa na Kapitolu $^{153}$. Miała ona bowiem celle $(24$ x 25 m) szerszą od pronaosu, co widać m.in. na zachowanym fragmencie odkrytego w 1983 przy Via Anicia planu miasta. Do wnętrza monumentu prowadziły masywne schody, dalej pronaos z czterema kolumnami od frontu oraz pojedynczym rzędem filarów na krótszych bokach. Pusty plac przy świątyni jest uważany za przestrzeń Circus Flaminius. Orientacja przybytku przedstawiona na planie sugeruje, że znajdował się on przy południowej krawędzi cyrku. Nieopodal świątyni stały prawdopodobnie dwa monumentalne posągi Dioskurów, które stanowią obecnie część balustrady na Piazza

152 Coarelli 1993: 245.

153 Vitr. 4. 8. 4. del Campidoglio ${ }^{154}$. W tym miejscu wystawiono także ołtarz. Za przybytkiem z kolei znajdowały się stojące nad Tybrem magazyny ${ }^{155}$.

Data budowy świątyni nie jest pewna. Wiemy jednak, że monument ten wyszczególniono w Fasti Antiates Maiores. Fakt, że kalendarz powstał prawdopodobnie około 46 r. p.n.e. może stanowić więc terminus ante quem fundacji aedes. Jej dies natalis przypadał trzynastego sierpnia, a według Attilio Degrassiego wszystkie przybytki, które zostały przedstawione w rzeczonym fasti pod tą datą, wpisano $\mathrm{W}$ porządku chronologicznym ${ }^{156}$. Jeśli więc przyjmiemy koncepcję archeologa za słuszną, to przybytek zbudowano później niż świątynię Fortuny Jeździeckiej (173 r. p.n.e.), której rok dedykacji stanowić będzie w tym wypadku terminus post quem ${ }^{157}$. W związku z powyższym fundacja

154 Coarelli 1997: 508-510. Posągi te zostały odnalezione już w okresie renesansu, jednak trudno jest określić ich dokładną lokalizację i kontekst archeologiczny. Datuję się je między II w. p.n.e. a II w. n.e.

155 Tucci, 2013: 91-127. Plan ten częściowo pokrywa się z fragmentami Forma Urbis (32h-i), na których zaznaczone są magazyny znajdujące się za świątynią.

156 Inscr. Ital. 13. 2: 191.

157 Pietilä-Castrén, 1987: 116. Świątynia Fortuny 
dla Kastora i Polluksa przy Cyrku Flaminiusza została wzniesiona prawdopodobnie pomiędzy 173 a 46 r. p.n.e.

Według hipotezy Coarellego datę tą można doprecyzować. Plutarch informuje bowiem, że w przybytku Kastora i Polluksa umieszczone zostały z inicjatywy Metellusa dzieła sztuki, w tym także obraz młodej hetery Flory, która była kochanką Gnejusza Pompejusza ${ }^{158}$. Niestety autor nie precyzuje, który z przedstawicieli rodu Cecyliuszy dokonał dedykacji. Zwykło się przyjmować, że obraz znajdował się w świątyni Kastora, którą w 117 r. p.n.e. odbudował na Forum Romanum Kwintus Cecyliusz Metellus Dalmacki ${ }^{159}$. Jednak pogląd ten stoi $\mathrm{w}$ sprzeczności $\mathrm{z}$ chronologią, gdyż biograf z Cheronei zaznaczył jednoznacznie, że hetera została przedstawiona w młodym wieku. Zważywszy na fakt, iż Pompejusz urodził się w 106 r. p.n.e. tabula jego kochanki musiała zostać zamówiona na początku I wieku p.n.e. $\mathrm{Na}$ tej podstawie Coarelli uważa, że przekaz ten nie dotyczy świątyni na Forum, a przybytku znajdującego się przy Circus Flaminius, który powstał prawdopodobnie w I wieku p.n.e. W takim wypadku za jego fundację odpowiadał być może Kwintus Cecyliusz Metellus Pius, który wspierał poczynania Pompejusza podczas wojny z Sertoriuszem. Co za tym idzie, świątynia mogła zostać ślubowana w czasie pobytu Metellusa Piusa w Hiszpanii, gdzie dowodził armią od 79 p.n.e., aż do momentu triumfalnego powrotu do Rzymu ${ }^{160}$. W związku z tym Coarelli uważa, że monument powstał po pompa triumphalis wodza, a pracę nad nim zostały sfinansowane ex manubiis ${ }^{161}$. Część badaczy uważa jednak, że to nie Metellus, a Publiusz Serwiliusz Watia odpowiedzialny był za budowę świątyni po

Jeździeckiej, została ufundowana z łupów wojennych zdobytych przez Kwintusa Fulwiusza Flakkusa podczas kampanii w Hiszpanii w roku 180 p.n.e. Jej lokalizacja jest jednak tematem wielu spekulacji. Fakt, że źródła wzmiankuja, iż stała ona przy Teatrze Pompejusza skłonił część badaczy do poszukania miejsca jej dedykacji na północ od tego monumentu w okolicach późniejszych Term Agryppy. Przypuszcza się bowiem, że świątynia ta została rozebrana pod koniec I w. p.n.e. Według innej koncepcji mogła się ona znajdować bliżej Circus Flaminius (tj. na południe od rzeczonego wyżej teatru). Brak pozostałości archeologicznych nie pozwala jednak na rozstrzygnięcie tej kwestii jednoznacznie.

158 Plut. Pomp. 2. 8.

159 Cic. Verr. 1. 154 ; Cic. Scaur. 46; Coarelli 2008: 74 .

160 Rich 2014: 251. Triumf wodza odbył się w roku 71 p.n.e.

161 Coarelli 1997: 505. swojej kampanii na Wschodzie z roku 74 p.n.e. Jednak zarówno w pierwszym jak i drugim przypadku są to tylko spekulacje, nie znajdujące potwierdzenia w dostępnym materiale źródłowym ${ }^{162}$.

Badacze nie sa także zgodni, co do konkretnej lokalizacji świątyni. Według Marisy Conticello De Spagnolis monument stał na miejscu współczesnego kościoła S. Tommaso Ai Cenci, gdzie odkryto kilka murów z okresu cesarstwa, interpretowanych jako ściany pronaosu przybytku Kastora i Polluksa ${ }^{163}$. Sceptycznie jednak do tego materiału podchodzi Tucci, który uważa, że odnalezione pozostałości są śladami po magazynach, znajdujących się w tej okolicy. Badacz, analizując dokładnie odkryty przy Via Anicia fragment planu miasta, przesuwa lokalizację przybytku kilka metrów na wschód od kościoła, w miejsce, w którym stoją obecnie budynki mieszkalne, a gdzie w 1910 roku odkryto fragmenty wykonanych z tufu ścian. Tucci równie sceptycznie podchodzi do ostatnich wyników prac archeologicznych, które prowadzili Paolo Ciancio Rossetto oraz Massimo Vitti ${ }^{164}$. Według tych badaczy odkryte pozostałości murów oraz podłogi (opus signinum) na Piazza delle Cinque Scole, są częścią przybytku Kastora i Polluksa. Jednak, jak zauważył Tucci, Vitti chcąc dopasować odkrytą strukturę do fragmentu planu z Via Anicia, zmienił jego skalę z 1:240 na 1:290, co implikuje szereg błędów (m. in. zmianę wielkości celi) ${ }^{165}$.

Niemniej przybytek dedykowany Kastorowi i Polluksowi został ufundowany w południowej części Circus Flaminius, a wybór takiej lokalizacji mógł być prozaiczny i wynikać z faktu, iż północna krawędź cyrku w I w. p.n.e. była już gęsto zabudowana przez szereg świątyń, a także portyków, które kumulowały sporą przestrzeń. Jednak, aby określić jego precyzyjną lokalizację potrzebne są dalsze prace archeologiczne.

\section{Konkluzje}

W okresie pomiędzy III-I w. p.n.e. wzniesiono w obrębie Circus Flaminius dziewięć świątyń, na budowę których całościowo bądź częściowo wykorzystano zdobyte podczas kampanii manubiae. Analizując te monumenty można wyciągnąć kilka wniosków.

162 De Caprariis 1996: 49-60.

163 M. Conticello De Spagnolis 1986: 91-96.

164 Ciancio Rossetto 2000: 234-235.

165 Vitti 2010 2010: 74-85; Tucci 2013: 97. 
Już przed formalnym wytyczeniem cyrku przestrzeń ta miała silne konotacje militarne. W III w. p.n.e. w miejscu tym zbudowano bowiem świątynię Bellony, przed którą $\mathrm{w}$ okresie Republiki rytualnie rozpoczynano wojny. Po ich zakończeniu Senat zbierał się wewnątrz aedes, aby wysłuchiwać raportów wodzów z kampanii, dyskutując przy tym nad przyznaniem bądź nie prawa do odbycia pompa triumphalis.

To właśnie triumfujący wodzowie wznieśli przy circus najwięcej monumentów. Tu znajdował się m.in. przybytek dedykowany Neptunowi, który ufundował prawdopodobnie wódz celebrujący triumf morski odniesiony podczas I wojny punickiej bądź I wojny iliryjskiej. W II w. p.n.e. po kampaniach zakończonych pompae triumphales wzniesiono także świątynię Pietas, Herkulesa przewodnika Muz, Jowisza Statora, a także Marsa. Ponadto w I w. p.n.e. w podobnych okolicznościach został ufundowany przybytek Kastora i Polluksa.

Nie wszystkie obiekty znajdujące się in circo wznieśli jednak wodzowie, którzy odbyli triumf bądź owację (tj. Bellony, Junony czy Diany). Mimo to również $\mathrm{i}$ te przybytki nawiązywały w sposób bezpośredni do tych wydarzeń stanowiąc „ersatz de symbole triomphal” ${ }^{166}$. We wszystkich świątyniach bowiem znajdowały się łupy, którymi duces dekorowali ich wnętrza. Wykorzystując, jak zauważył Erich S. Gruen, ,the fruits of war in the service of advancement of culture" 167 .

Problem lokalizacji oraz osób odpowiedzialnych za fundację większości przedstawionych świątyń, jest obecnie jednoznacznie wyjaśniony. Szczególnie w przypadku monumentów, które znajdowały się w strefie pomiędzy północną krawędzią cyrku oraz Polem Marsowym. Dyskusyjna pozostaje jednak kwestia związana z lokalizacją m.in. przybytku Diany czy Kastora i Polluksa. Niewykluczone jednak, że przyszłe badania archeologiczne prowadzone w obszarze pomiędzy Tybrem a Via del Portico di Ottavia przyniosą ostateczne rozstrzygnięcia, co do lokalizacji owych monumentów.

Skróty

CIL - Corpus Inscriptionum Latinarum

ILS - Inscriptiones Latinae Selectae, ed. H. Dessau, Berolini 1954-1955

166 Aberson $1994: 152$.

167 Gruen 1992: 109.
Inscr. Ital. XIII - Inscriptiones Italiae XIII, ed. A. Degrassi, Rome 1937

LTUR - Lexicon Topographicum Urbis Romae, ed. E.M. Steinby

MAR - Mapping Augustan Rome, Journal of Roman Archaeology suppl. 50, 2002

RRC - Crawford M.H., Roman Republican Coinage, Cambridge 974

\section{Literatura}

Aberson M. 1994. Temples votifs et butin de guerre dans la Rome republicaine, Rome.

Bastien J. 2008. Les temples votifs de la Rome républicaine: monumentalisation et célébration des cérémonies du triomphe w: Roma illustrata. Représentations de la ville, Caen, 29-48.

Ball Platner S., Ashby T. 1929. A Topographical Dictionary of Ancient Rome, London

Bernard S. 2010. Pentelic marble in architecture at Rome and the Republican marble trade, Journal of Roman Archaeology 23, 35-54.

Bloy D. 1999. Greek War Booty at Luna And the Afterlife Of Manius Acilius Glabrio, Memoirs of the American Academy in Rome 43-44, 49-61.

Boyd M. 1953. The Porticoes of Metellus and Octavia and their Two Temples, Papers of the British School at Rome 21, 152-159.

Bravi A. 2014. Griechische Kunstwerke im Politischen Leben Roms und Konstantinopels, Berlin, New York.

Broughton T.R.S. 1951. The Magistrates of the Roman Republic 1, New York.

Castagnoli F. 1948. Campo Marzio nell'antichità, Atti della Academica Nazionale dei Lincei 8. 1, 91-193.

Castagnoli F. 1961. La pianta marmorea di Roma antica: forma urbis Romae, by G. Caretino, M. Colini, L. Cozza, G. Gatti (Reviwe), Gnomon 33, 604-610.

Ciancio Rossetto P. 1999. Pietas, aedes in Foro Holitorio / in Circo Flamini”, LTUR 4, 86.

Ciancio Rossetto P. 2000. Castor et Pollux in Circo, aedes Castori in Circo Flaminio, LTUR 5, 234-235.

Coarelli F. 1968a. Il tempio di Bellona, Bullettino della Commissione Archeologica Comunale di Roma 80, 37-72.

Coarelli F. 1968b . L'ara di Domizio Enobarbo" e la cultura artistica in Roma nel II secolo a.c., Dialoghi di Archeologia II, 302-368.

Coarelli F. 1993. Castor et Pollux in Circo, aedes Castori in Circo Flaminio, LTUR 1, 245. 
Coarelli F. 1997. Il Campo Marzio: dalle origini alla fine della Repubblica, Roma.

Coarelli F. 2000. Via Triumphalis, LTUR 5, 148.

Coarelli F. 2008. Rome and Environs: An Archaeological Guide, Berkeley.

Conticello De Spagnolis M. 1986. Nuove osservazioni sull'area del tempio dei Dioscuri in circo Flaminio, Bullettino della Commissione Archeologica Comunale di Roma 91, 91-96.

Davies P. 2017. Architecture and Politics in Republican Rome, Cambridge.

De Caprariis F. 1996. P. Servilio Isaurico e un 'nuovo' monumento della Roma tardo-repubblicana, Rivista dell'Istituto di Archeologia e Storia dell'Arte19-20, 49-60.

De Nuccio 2011: La decorazione architettonica del tempio di Bellona, Bullettino della Commissione Archeologica Comunale di Roma.

Don Miller R. 2013. Monumental Rome. W: Cambridge Companion to Ancient Rome, P. Erdkamp (ed.), Cambridge, 191-192.

Flower H. 1996: Ancestor Masks and Aristocratic Power in Roman Culture, Oxford.

Gatti G. 1960: Dove erano situati il Teatro di Balbo e il Circo Flaminio? "Capitolium" 35, s. 3-12.

Gianfrotta P. 1985: Indagini nell'area della porticus Philippi, Bietti Sestieri 2, 376-384.

Gros P. 1978. Architecture et société à Rome et en Italie centro-méridionale aux deux derniers siècles de la République, Bruxelles.

Gruen E. 1992. Culture and National Identity in Republican Rome, Ithaca.

Gurval R. A. 1998. Actium and Augustus: The Politics and Emotions of Civil War, Michigan.

Gwyn Morgan M. 1971 The Portico of Metellus: A Reconsideration, Hermes 99.4, 480-505.

La Rocca E. 1987. L'adesione senatoriale al 'consensus': i modi della propaganda augustea e tiberiana nei monumenti in circo Flaminio, w: L'Urbs, Rome, 347-372.

La Rocca 1993. Columna Bellica, LTUR 1, 300301.

Mancorda D. 1990. II Tempio di Vulcano in Campo Martio, Dialoghi di Archeologia 3.8, 35-51.

Maxfield V. 1981 The Military Decorations of the Roman Army, Los Angeles.

Muccigrosso J. D. 2006. Religion and politics: did the Romans scruple about the placement of their temples, w: Religion in the Republican Rome, E. Schultz, P. B. Harvey (eds), Cambridge, 188-191.

Orlin E 2002. Temples, Religion and Politics in the Roman Republic, Boston.

Pape M. 1975. Griechische Kunstwerke aus Kriegsbeute und ihre öffentliche Aufstellung in Rom.
Von der Eroberung von Syrakus bis in augusteische Zeit, Hamburg 1975.

Petruccioli G. 2002. Circus Flaminius, MAR, 86-87.

Pietilä-Castrén L. 1987. Magnificentia publica, the Victory Monuments of the Roman Generals in the Era of the Punic Wars, Helsinki.

Popławski M. 2011. Bellum Romanum, Sakralność wojny i prawa rzymskiego, Lublin.

Richardson jr. L. 1992. A New Topographical Dictionary of Ancient Rome, London.

Rich J. 2014. The Triumph in the Roman Republic: Frequency, Fluctuation and Policy, w: The Roman Republican Triumph Beyond the Spectacle, C. Hjort Lange, F. J. Vervaet (eds), Roma.

Rodriguez-Almeida E. 1991-1992. Diversi problemi connessi con la lastra n. 37 della Forma Urbis Marmorea e con la topografia in Circo e in Campo, Rendiconti Accademia Romana di Archeologia 64.

Shatzman I. 1972. The Roman General's Authority over Booty, Historia 21, 177-205.

Shatzman 1955. Senatorial Wealth and Roman Politics, Bruxelles 1975.

Tortorici E. 1988. Il tempio presso S. Salvatore in Campo: V. Vespignani ed Ermodoro di Salamina, Quaderini di topografía antica 10, 59-76.

Tucci P. L. 1997. Dov'erano il tempio di Nettuno e la nave di Enea? Bullettino della Commissione Archeologica Comunale di Roma 98.

Tucci P. L. 2000. Neptunus, aedes in Campo, aedes in Circo", LTUR 5, 279.

Tucci P. L. 2013. The marble plan of the Via Anicia and the Temple of Castor and Pollux in Circo Flaminio: the state of the question, Papers of the British School at Rome 81, 91-127.

Weigel R. 1998. Roman Generals and the Vowing of Temples, 500-100 B.C., Classica et Mediaevalia 49, 119-142.

Wiseman T. P. 1974: The Circus Flaminius, Papers of the British School at Rome 42, 3-26.

Wiseman T.P. 1976: Two Questions on the Circus Flaminius, Papers of the British School at Rome 44.

Viscogliosi A. 1993a. Circus Flaminius, LTUR 1, 269-272.

Viscogliosi A. 1993b. Bellona, aedes in Circo, LTUR 1, 190-2.

Viscogliosi A. 1995. Diana, aedes in Circo, LTUR 2,14 .

Viscogliosi A. 1996a. Hercules Musarum, aedes. LTUR 3, 17-19.

Viscogliosi 1996b. Iuno Regina, aedes in Campo, ad Circum Flaminium, LTUR 1., 126-128.

Viscogliosi 1996. Iuppiter Stator, aedes ad Circum, LTUR 3, 157-159. 
Vitti M. 2010. Aedes Castoris et Pollucis in Circo, Bullettino della Commissione Archeologica Comunale di Roma, 74-85.

Zevi F. 1993. Per l'identificazione della porticus Minucia frumentaria, Mélanges d'archéologie et d' historie de l'Ecole française de Rome 105, 661-708.

Zevi F. 1996. Mars in circo, LTUR 3, 227-229.
Ziółkowski A. 1980. Łupy wojenne Rzymian III-I wiek p.n.e. Pochodzenie, podziat, sposób wykorzystania, Warszawa (maszynopis w zbiorach Uniwersytetu Warszawskiego).

Ziółkowski A. 1992 The Temples of Mid-Republican Rome and Their Historical and Topographical Context, Roma.

Adam Jakub Jarych ORCID 0000-0002-6538-9956

Uniwerystet Mikołaja Kopernika w Toruniu

Wydziat Historii

Instytut Archeologii adamjarych@umk.pl 